\title{
演題番号 10
}

\author{
新生児に扣ける体外循環 \\ 一 循環停止之低流量体外循環の比較一 \\ 聖マリア病院 臨床工学室 \\ 中島康弘江口裕三 \\ 同 心㖪血管外科 \\ 藤 堂 景 茂
}

はじめに

先天性心疾患们対する乳児期の成續は，近年い ちじるしく向上を示したが，新生児期の開心術に ついては，まだ解決すべき問題が残されている。 今回，当施設における過去 5 年間の新生児期 14 例 の成績から, 循環停止と低流量体外循環の比較に ついて報告する。

対

対象は1983年1月から 1987年1月までの新生 児開心術14例で，内訳はTAPVR 5例，HPLH 2 例, TGA, ASD+VSD, VSD+COA, ASD+VSD +CoA, AS+MS+PDA, VSD, PAの各々1例で

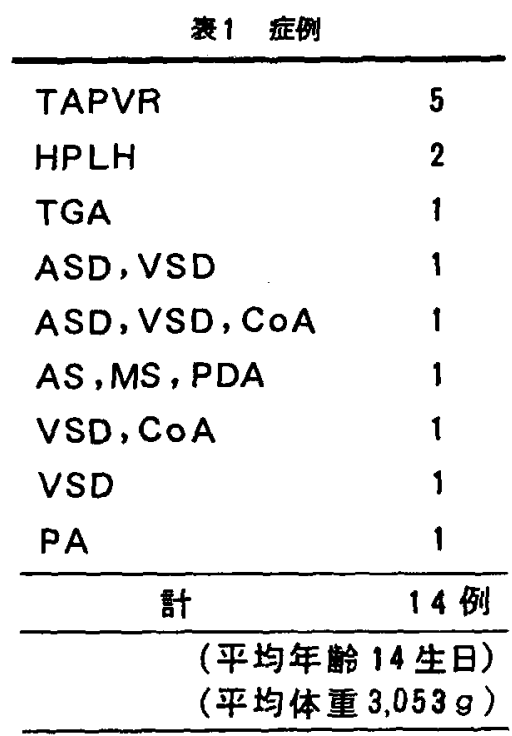

ある，また，平均年龄は14生日で，平均体重は 3,0539である(表 1)。

\section{方 法}

症例を偱環停止併用群 8 例之低流量併用体外循 環群 6 例に分けた。麻酔法は，両群ともにGO morphineまたはNLAにて行ない，循環停止併用群 は体表面冷却および中心冷却にて，直腸温18C以 下まで冷却した，低流量併用体外循環群は，中心 冷却にて直腸温度25３0Cの中等度低体温を行な った.

なお，開心術の際に中枢神経系の障害の有無に

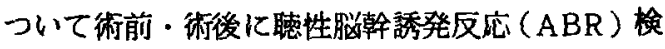
查を同時に測定した（写真 1$)$.

\section{成 綂}

䛻環停止併用群之低流量体外循環群の年龄, 体 重估各々11生日と18生日，それに体重は $2.9 \mathrm{~kg}$ と

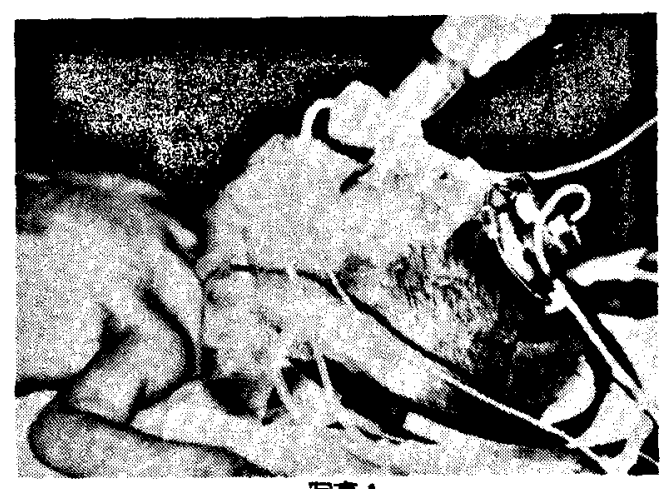

写重 1 
$3.2 \mathrm{~kg}$ であり, 両群内には有意差は認められなか った。なお，体外循環時間，大動脈遮断時間は各 々有意差が認められた（表 2 ）。

手術後の死亡率 (遠隔死含む)は, 循環停止併用 群 $87.5 \%$, 低流量体外循環群 $50 \%$ と両群間に有意 差は認められる。(表 3 )。

予後に影響を及ぼす諸因子を検討してみると， 循環停止併用群においては，手術時の体重が少な からず関与しているように示唆される。低流量体 外循環群では, 生存群之死亡群に手術時体重の有

表 2

\begin{tabular}{|c|c|c|}
\hline & 䛻㯰停止併用群 & 低流笽併用体外䛻瓄群 \\
\hline 路 & $5 \mathrm{~d} \sim 28 \mathrm{day}(11.6 \mathrm{day})$ & $7 \sim 28$ day ( 18.3 day $)$ \\
\hline 重 & $2.9 \mathrm{~kg}$ & $3.2 \mathrm{~kg}$ \\
\hline 体外䛻環時間 & 225 分 05 秒 & 120 分 06 秒 \\
\hline 大動脈遮断時間 & 137 分 28秒 (1 例は Aocluno 無し) & 68 分 18 秒 \\
\hline 䛻彊停止時間 & 40 分 32 秒 & \\
\hline 体表面棈 & 0.18 & 0.21 \\
\hline
\end{tabular}

表 3

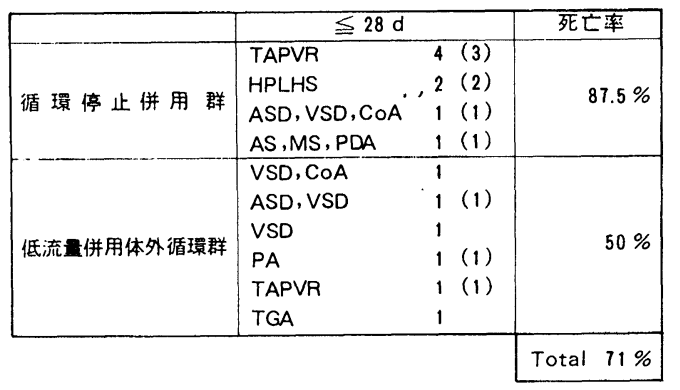

意差は認められなかった。(表 4).

つぎに，中枢神経系に障害を与えるかどうかを 検索するために, 聴性脳幹誘発反応検查を行なっ た。 循環停止併用群と体外循環群を比較すると, ABRの各波ピーク潜時は循環停止併用群の方が著 しく延長しているてとが明確に判る(図 1). なお,

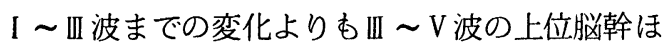
ご潜時の延長は著しく, 特に中脳の機能を示す $\mathrm{V}$ 波潜時の延長は顕著である（図 1).

\section{考 察}

新生児の治療成績向上に関し, 補助手段が大き な役割を果たしていることは言うまでもない。

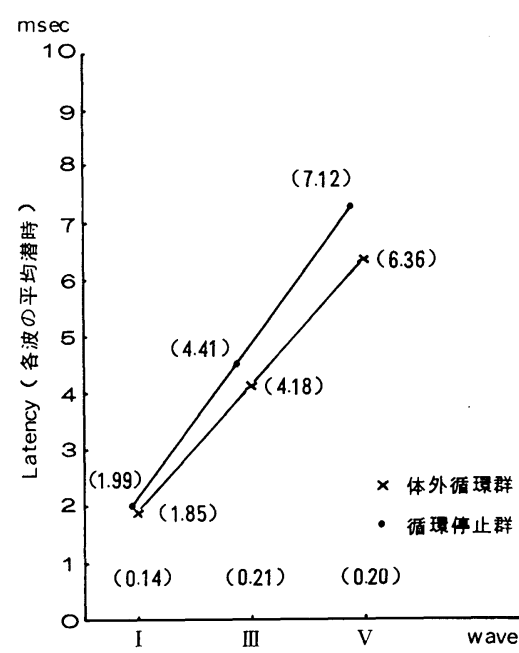

図 1 体外循環群之循環停止群之の比較 $\mathrm{X}$ 体外循環群,
循環停止群

表 4

\begin{tabular}{|c|c|c|c|c|c|c|c|c|}
\hline & 症 & $\begin{array}{l}\text { 年 } \\
\text { 湛 }\end{array}$ & 病 名 & 体重 & $\begin{array}{c}\begin{array}{c}\text { 体外䛻環時間 } \\
\text { (分) }\end{array}\end{array}$ & $\begin{array}{c}\text { 大動脈遮断時間 } \\
\text { (分) }\end{array}$ & $\begin{array}{c}\text { 循琭停止時間 } \\
\text { (份) }\end{array}$ & $\begin{array}{c}\text { 状 態 } \\
\text { (䔔唡死含む) }\end{array}$ \\
\hline \multirow{8}{*}{$\begin{array}{l}\text { 䛻 } \\
\text { 環 } \\
\text { 停 } \\
\text { 止 } \\
\text { 併 } \\
\text { 用 } \\
\text { 群 }\end{array}$} & 1 & $8 d$ & TAPVR & 2820 & 198 & 111 & 43 & 死 亡 \\
\hline & 2 & $5 d$ & TAPVR & 3100 & 165 & 63 & 65 & 11 \\
\hline & 3 & $8 d$ & ASD, VSD, COA & 2500 & 142 & 97 & 51 & " \\
\hline & 4 & $5 d$ & $\mathrm{HPLH}$ & 2200 & 304 & 280 & 78 & 11 \\
\hline & 5 & $12 d$ & HPLH & 3300 & 222 & 142 & 29 & " \\
\hline & 6 & $28 d$ & AS, MS, PDA & 3300 & 374 & 154 & 37 & " \\
\hline & 7 & $17 d$ & TAPVR & 3700 & 160 & 92 & 10 & 生存 \\
\hline & 8 & $10 \mathrm{~d}$ & TAPVR & 2470 & 238 & - & 8 & 死亡 \\
\hline \multirow{6}{*}{ 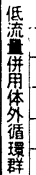 } & 9 & $17 d$ & VSD, COA & 3800 & 88 & 52 & - & 生 存 \\
\hline & 10 & $7 d$ & $A S D, V S D$ & 3200 & 130 & 54 & - & 死 ᄃ \\
\hline & 11 & $25 d$ & VSD & 3300 & 81 & 59 & - & 生 存 \\
\hline & 12 & $28 d$ & PA & 3180 & 54 & 27 & - & $"$ \\
\hline & 13 & $25 d$ & TAPVR & 2640 & 199 & 133 & - & 死亡 \\
\hline & 14 & $14 d$ & TGA & 3240 & 166 & 83 & - & 生 存 \\
\hline
\end{tabular}


現在，使用されている補助手段には，1）表面 冷却超低体温法，2）体外循環併用超低体温循環 停止法，3）低体温下低流量還流法，4）通常低 体温下体外循環法，5）拍動流体外循環法などが ある.

体外循環併用超低体温循環停止法は, 手術操作 が容易であるてとより行なわれている。しかし， 術後脳神経障害の報告が見られるようになってき た，我々も循環停止法について，中枢神経系の影 響を調べる目的にて, 聴性脳幹誘発反応の潜時を 測定した結果, 循環停止併用法の脳幹への影響は, 体外循環法に比べて大きく，かつ身体の小さい症 例ほど影響を受けやすいと示唆された。

循環停止併用法と体外循環法を症例で比較した
ら，病型やその他条件の違いはあるけれどあ少な からずとむ循環停止を行なわないが良いように示 唆される.

\section{まとめ}

新生児期の補助手段について, 循環停止法と体 外循環法を実験例に基づき検討した結果, 体外循 環法にて手術成績の改善が認められた。

中枢神経系への影響についても, 同様に循環停 止法が影響を大きく受けているものと考えられた. したがって, 超低体温下であっても主要臓器の障 害を避けるため, 流量を保つほうが良いように思 われる。 